\title{
The Past, Present and Future of the Relation between the European Court of Justice and the European Court of Human Rights
}

\author{
Federico Fabbrini* and Joris Larik**
}

\begin{abstract}
Opinion 2/13, by which the CJEU declared incompatible with the EU treaties the long-negotiated draft agreement on EU accession to the ECHR, came as a shock to many observers. Yet, the relation between the ECJ and the ECtHR has a glorious past, and can continue to have a bright future. While the dust kicked up by Opinion 2/13 settles, the article takes a step back and puts the ruling of the CJEU in a wider context. It recalls the long-standing historical relations between the CJEU and the ECtHR, and discusses the possible scenarios that may open up in the future. In particular, it claims that, even in the aftermath of Opinion 2/13, a virtuous competition between the CJEU and the ECtHR can have beneficial effect for the protection of fundamental rights, as evidenced by the case of judicial review of targeted UN sanctions. At a time of increasing frustration and preoccupation on the relation between the CJEU and the ECtHR, the article strikes a note of optimism, suggesting that the interaction between the two European supranational courts can still play a positive role for fundamental rights in Europe.
\end{abstract}

\section{Introduction}

The relationship between the Court of Justice of the European Union (CJEU) and the European Court of Human Rights (ECtHR) has been one of the most researched topics in the field of European law. The recent Opinion 2/13 of the CJEU, ${ }^{1}$ which found that the draft agreement on the accession of the European Union (EU) to the European Convention on Human Rights (ECHR) was not compatible with EU treaties, has attracted much attention-if not shock-and raised new questions about the interactions between the two European

* Associate Professor of European \& International Law at iCourts (Center of Excellence for International Courts), at the Faculty of Law of the University of Copenhagen, Centre of Excellence for International Courts. This research is funded by the Danish National Research Foundation Grant no. DNRF105. Email: federico.fabbrini@jur.ku.dk.

** Assistant Professor of Comparative, EU \& International Law at the Faculty of Governance and Global Affairs, Leiden University and Senior Researcher at The Hague Institute for Global Justice. Email: j.e.larik@luc.leidenuniv.nl.

1 Opinion 2/13, ECLI:EU:C:2014:2454. 
supranational courts. As the dust kicked up by the opinion settles, the purpose of this article is to take a step back, and examine the past, present, and possible future, of the relations between the CJEU and the ECtHR. ${ }^{2}$ The article summarizes the complex and evolving historical connections between the highest courts of the EU and ECHR legal orders; it takes stock of the current effects of Opinion 2/13; and, on this basis, it seeks to suggest ways in which the CJEU and the ECtHR may still find ways to coexist in a state of virtuous competition in the years to come.

As the article explains, the relation between the CJEU and the ECtHR has evolved over time, going through phases of separation, confrontation, and comity. While in 2013 the EU and ECHR institutions had reached an agreement on the accession of the EU to the ECHR, which would have redefined the relations between the two European supranational courts, in 2014 the CJEU found the draft accession agreement in Opinion 2/13 to be incompatible with EU law. Much literature has already evaluated the ruling of the CJEU. ${ }^{3}$ This article does not engage in this exercise. Rather, on the assumption that judicial practice will have to continue shaping the interaction between the CJEU and the ECtHR, this article considers what possible scenarios open up for the future relations between the two European supranational courts. To this end, the article discusses both the possibility of a continuing committal approach between the CJEU and the ECtHR, and the risks associated with a new confrontation. As an alternative, it suggests that the two courts may still find ways to coexist with positive effects for the protection of fundamental rights in Europe.

In particular, the article submits that a virtuous competition between the CJEU and the ECtHR can produce positive effects for the protection and promotion of fundamental rights in Europe. ${ }^{4}$ To substantiate its claim, the article considers the example of judicial review of United Nations (UN) counter-terrorism sanctions, and emphasizes how in cases like Kadi and Nada, the CJEU and the ECtHR have been able to strengthen each other, turning their competition into a powerful mechanism to expand the protection of fundamental rights-even against strong national and international security pressures to water down human rights standards. Although this represents just an example, the article suggests that a competition between the two European courts involved in human rights protection may wield a positive impact in Europe,

\footnotetext{
2 The article's title draws from the famous work by Bruno de Witte, 'The Past and the Future Role of the European Court of Justice in the Protection of Human Rights' in Philip Alston (ed.), The EU and Human Rights (Oxford: Oxford University Press, 1999) 859.

3 Compare Steve Peers, 'The EU's Accession to the ECHR: the Dream Becomes a Nightmare' (2015) 16 German Law Journal, 213 (strongly criticizing the Opinion of the CJEU) with Daniel Halberstam, "It's the Autonomy, Stupid!" A Modest Defense of Opinion 2/13 on the EU Accession to the ECHR, and the Way Forward' (2015) 16 German Law Journal, 105 (defending the ECJ Opinion 2/13).

${ }_{4}^{4}$ See generally Federico Fabbrini, Fundamental Rights in Europe (Oxford: Oxford University Press, 2014).
} 
producing a race to the top in the protection of fundamental rights. In other words, at a time when much frustration and preoccupation exist on the future of the relation between the CJEU and the ECtHR, the article attempts to illuminate a possible path forward, in which the two supranational courts can jointly promote the growth and development of human rights and the rule of law in Europe.

The article is structured as follows. Section II provides an overview of the past relations between the CJEU and the ECtHR, sketching the evolution of the interconnections between the two European supranational courts from their foundation, in the post-War period, up to the first decade of the twenty-first century, at the time when the Lisbon Treaty and the 14th Additional Protocol to the ECHR entered into force. Section III focuses on the present state of the relations between the CJEU and the ECtHR, analysing the draft agreement on the accession of the EU to the ECHR, as well as its rejection by the CJEU in Opinion 2/13. Section IV, lastly, considers the possible future of the relations between the CJEU and the ECtHR, outlining alternative scenarios in the interactions between the two European supranational courts, and suggesting that a virtuous competition between the CJEU and the ECtHR, as revealed in the case of judicial review of UN sanctions, would be beneficial to the promotion and protection of human rights in Europe.

\section{The past: the long history of Europe's supranational courts}

This section examines the history of the relationship between the CJEU and the ECtHR until the entry into force of the Lisbon Treaty, exploring the linkages that these courts have created between their respective organizations. ${ }^{5}$ The ECHR was adopted in 1950, in the framework of the Council of Europe (CoE), an organization established in 1949 under British sponsorship to promote democracy and the rule of law in Europe. ${ }^{6}$ The forbear of the EU was created in 1951 by the Treaty of Paris on the European Coal and Steel Community (ECSC) as a result of the cooperation between France and Germany, joined by Italy and the Benelux countries, in the management of a strategic industrial sector. ${ }^{7}$ Both the $\mathrm{CoE}$ and the EU pursued the aim of ensuring peace and prosperity in Europe through greater integration between

\footnotetext{
5 See Paul Gragl, The EU's Accession to the ECHR (Oxford: Hart Publishing, 2013) and Vasiliki Kosta, Nikos Skoutaris, and Vassilis Tzevelekos (eds), The EU Accession to the ECHR (Oxford: Hart Publishing, 2014).

${ }^{6}$ See Mikael Madsen and Chris Thornhill (eds), Law and the Formation of Modern Europe: Perspectives from the Historical Sociology of Law (Cambridge: Cambridge University Press, 2014).

7 See Mark Gilbert, Surpassing Realism: The Politics of European Integration since 1945 (Washington, DC: Rowman \& Littlefield Publishers, 2003).
} 
their states. ${ }^{8}$ Nevertheless, the two organizations had different long-term perspectives and developed alternative institutional means to achieve them. While the CoE pursued a limited intergovernmental agenda and was mainly conceived as the instrument to prevent the resurgence of fascism or the victory of communism in Europe by creating mechanisms to supervise and assist Member States in the field of human rights, the EU had a broader aspiration to establish a political and economic union among the European states. ${ }^{\text {? }}$

As Gráinne de Búrca has thoroughly explained, ${ }^{10}$ already in the early 1950 s clear attempts were made to ensure a formal connection between the $\mathrm{EU}$ and the ECHR. In particular, the Treaty establishing the European Political Community (EPC), drafted in 1952-53 as a follow-up of the ESCS, provided that the ECHR would become an integral part of the basic law of the EPC and set up a mechanism by which the CJEU could relinquish jurisdiction to the ECtHR on matters of principle concerning the ECHR. The abandonment of the EPC Treaty after France's failure to ratify the European Defense Community Treaty in 1954, however, lead the Member States to follow a different strategy of integration, focused on 'a carefully limited set of economic concerns rather than by immediately pursuing an open-ended political agenda. ${ }^{11}$ Hence, the 1957 Rome Treaty, establishing the European Economic Community (EEC) and the European Atomic Energy Community (Euratom), did not address the issues of the protection of fundamental rights in the EU system and of the relations between the EU and the ECHR.

Since then, the issue of the official accession of the EU to the ECHR has continued to remain on the table, but has never been accomplished. However, despite the absence of a formal link between the EU and the ECHR, over the course of the last 60 years, a number of informal connections between the two have emerged. A key role in ensuring a practical liaison between the EU and the ECHR has been provided by the CJEU and the ECtHR. Through their case law, the two European supranational courts managed to create a judicial relationship between the EU and the ECHR, and the ECtHR even experimented with (limited) forms of review of EU measures. The case law of the ECtHR on the review of EU measures has evolved over time on the basis of two factors: first, the nature of the dialogue with the CJEU; ${ }^{12}$ and second, the broader constitutional transformations taking place in the European multi-level

\footnotetext{
${ }^{8}$ See Andrew Moravcsik, 'The Origin of Human Rights Regimes: Democratic Delegation in Postwar Europe' (2000) 54 International Organization, 217.

${ }^{9}$ See Tony Joris and Jan Vandenberghe, 'The Council of Europe and the European Union: Natural Partners or Uneasy Bedfellows?' (2009) 15 Columbia Journal of European Law, 1.

${ }^{10}$ Gráinne de Búrca, 'The Road Not Taken: The European Union as a Global Human Rights Actor' (2011) 105 American Journal of International Law, 649.

${ }^{11}$ Ibid 652.

12 On judicial dialogue generally see Anne-Marie Slaughter, 'A Global Community of Courts' (2003) 44 Harvard International Law Journal, 191, and on the dialogue between the CJEU and the ECtHR specifically see Sionaidh Douglas-Scott, 'A Tale of Two Courts: Luxembourg, Strasbourg and the Growing European Human Rights Acquis' (2006) 43 CML Rev, 629.
} 
constitutional system. ${ }^{13}$ In this regard, it is possible to distinguish between three different phases, in which the question whether acts by the EU could be subject to review for compatibility with the ECHR received different judicial answers.

\section{A. The phase of parallel development}

From the late 1950s until the early 1990s, the EU and the ECHR developed largely along separate lines and the possibility of reviewing the action of the EEC (and ECSC and Euratom) for compatibility with the ECHR was explicitly excluded. After the failure of the grand project of political integration enshrined in the EPC, the EU Member States consciously decided to pursue a form of economic integration in which fundamental rights were left to the side. According to the drafters of the EEC and Euratom Treaties, the EU would no longer 'have a substantial role in promoting and protecting human rights, and it would not work along-side the [CoE] and the ECHR system for that purpose'. ${ }^{14}$ Thus, the EEC Treaty did not contain a reference to fundamental rights and no formal institutional link was in place to connect the EU to the ECHR. This opened a period during which relations between the EU and the ECHR were rather weak.

This does not mean that this time was characterized by total indifference between the EEC and the ECHR. As early as in the late 1960s, in fact, the CJEU affirmed that fundamental rights formed an integral part of the general principles of law which the CJEU protected. ${ }^{15}$ It is a matter of debate whether this case law was a defensive move to shield the judge-made doctrines of direct effect and supremacy, ${ }^{16}$ or rather a pro-active step in the protection of fundamental rights in Europe. ${ }^{17}$ Be that as it may, the main sources of inspiration for the development of a judicial EU Bill of Rights were the common constitutional traditions of the Member States and, as stated in the 1974 Nold decision, 'international treaties for the protection of human rights on which the Member States have collaborated or of which they are signatories'. ${ }^{18}$ In the

\footnotetext{
13 On the concept of multi-level constitutionalism see in particular Ingolf Pernice, 'Multilevel Constitutionalism in the European Union' (2002) 27 EL Rev, 511; Ingolf Pernice, 'The Treaty of Lisbon: Multilevel Constitutionalism in Action' (2009) 15 Columbia Journal of European Law, 349.

14 De Búrca (n 10) 665.

15 See Case 29/69, Stauder, ECLI:EU:C:1969:52; and Case 11/70, Internationale Handelsgesellschaft, ECLI:EU:C:1970:114..

16 See eg Frank Schimmelfennig, 'Competition and Community: Constitutional Courts, Rethorical Action, and the Institutionalization of Human Rights in the European Union', in Bernard Rittberger and Frank Schimmelfennig (eds), The Constitutionalization of the European Union (Abingdon: Routledge, 2007) 100.

17 This position has been persuasively argued in a recent work by Brun-Otto Bryde, 'The ECJ's Fundamental Rights Jurisprudence-A Milestone in Transnational Constitutionalism' in Miguel Maduro and Loïc Azoulai (eds) The Past and Future of EU Law: The Classics of EU Law Revisited on the 50th Anniversary of the Rome Treaty (Oxford: Hart Publishing, 2010) 120.

18 Case 4/73, Nold, ECLI:EU:C:1974:51, para. 13.
} 
Rutili decision of $1975,{ }^{19}$ the CJEU clarified that the ECHR represented a source of special importance, also in light of the fact that all EEC Member States where parties to the ECHR and subject to its supervisory machinery. ${ }^{20}$

Nevertheless, despite the reference to the ECHR by the CJEU, the absence of a formal accession of the EEC to the ECHR represented during this period an insurmountable obstacle to the review of the action of the EEC by the ECHR bodies. ${ }^{21}$ Although during the 1970 s several proceedings where brought against the EEC before the European Commission on Human Right (ECommHR), 'they were all declared inadmissible on the grounds that the Community was not a party to the Convention'.22 Before the entry into force of the 11th Additional Protocol to the ECHR in 1998, in fact, all applications to the ECHR organs were preliminarily assessed on procedural grounds by the ECommHR, a political organ with the function to filter the complaints and advance a friendly settlement of the dispute. The ECtHR could intervene only afterwards, if the individual recourse was not inadmissible or manifestly ill founded. ${ }^{23}$

As a matter of fact, for almost 40 years the ECtHR 'never had the opportunity to rule either on cases against the Community or on cases against Member States concerning Community acts, because all such cases were declared inadmissible by the [ECommHR]'. ${ }^{24}$ As stated in Confédération Française Démocratique du Travail (CFDT), ${ }^{25}$ and restated in subsequent rulings of the ECommHR, ${ }^{26}$ both the 'European Communities itself, ${ }^{27}$ and the 'Member States of the European Communities jointly'28 or 'the Member States of the European Communities severally', ${ }^{29}$ fall 'outside the Commission's jurisdiction ratione personae. ${ }^{30}$ In conclusion, for a first, long, judicial phase, no possibility to review the action of the EEC institutions was acknowledged by the ECHR bodies and the two supranational organizations

\footnotetext{
19 Case 36/75, Rutili, ECLI:EU:C:1975:137.

20 See Marta Cartabia, 'L'ora dei diritti fondamentali nell'Unione Europea' in Marta Cartabia (ed.), I diritti in azione (Bologna, Il Mulino, 2007) 19.

21 See Aida Torres Pérez, Conflicts of Rights in the European Union (Oxford: Oxford University Press, 2009).

22 Henry Schermers, 'Case Note: Matthews' (1999) 36 CML Rev, 674.

23 See generally Olivier De Schutter, International Human Rights Law (2nd edn, Cambridge: Cambridge University Press, 2011) 983-1005 (explaining procedures before the ECtHR).

24 Schermers (n 22) 674.

25 ECommHR, Confédération Française Démocratique du Travail (CFDT) v EEC, no. 8030/77, decision of 10 July 1978.

${ }^{26}$ Cf also ECommHR, Dufay v EEC, no. 13539/88, decision of 19 January 1989 (rejecting recourse against the EEC).

27 Confédération Française Démocratique du Travail (CFDT) (n 25) para. 3.

28 Ibid at para. 4.

29 Ibid at para. 5.

30 Ibid at para. 3.
} 
created in post-Second World War Europe largely developed in parallel worlds. ${ }^{31}$

\section{B. The phase of confrontation}

During the 1990s, the dynamics of the relationship between the ECHR and the EU accelerated dramatically and the possibility of a review by the ECtHR of the acts of the EU became a highly likely scenario. ${ }^{32}$ The background to the judicial developments taking place in this period can be found in the momentous constitutional transformations fostered by the fall of the Berlin Wall and the transition to democracy of the countries of Central and Eastern Europe. These events represented a turning point in the history of the EU and the ECHR and were the origin of profound institutional reforms in the framework of both the $\mathrm{CoE}$ and the EU. These reforms aimed to strengthen the role of the two supranational organizations, each considered essential to ensure the re-unification of a Europe no longer divided by the Iron Curtain.

In the EU framework, the reunification of Germany primarily offered the opportunity to deepen the process of European integration among the Member States and re-launch the political agenda which had been abandoned in 1955 . Hence, with the Maastricht Treaty of 1992, the EEC was transformed into the European Community (EC) and endowed with new powers, including Economic and Monetary Union, ${ }^{33}$ and was embedded in a broader organization, the EU, with competence also in the area of Common Foreign and Security Policy and Justice and Home Affairs. In the field of fundamental rights, then, Article F EU Treaty (later renumbered as Article 6 by the Amsterdam Treaty) codified the principle already elaborated in the case law of the CJEU that the EU 'shall respect fundamental rights, as guaranteed by the [ECHR] and as they result from the constitutional traditions common to the Member States, as general principles of Community law', thus enhancing the role of the CJEU as a court with an explicit mandate to protect human rights in the EU.34

In the CoE system, otherwise, the dissolution of the Soviet bloc represented a great opportunity to widen the territorial application of the ECHR since all former Communist countries, step by step, became signatories to the ECHR. At the same time, as the accessions to the ECHR spread eastward, the institutional machinery for the protection of fundamental rights in the ECHR system was

\footnotetext{
31 See also Evert Alkema, 'The EC and the European Convention on Human Rights: Immunity and Impunity for the Community?' (1979) 16 CML Rev, 48.

32 See Joseph Weiler, 'Fundamental Rights and Fundamental Boundaries', in Nanette Neuwahl and Allan Rosas (eds), The European Union and Human Rights (London: Kluwer, 1995) 51.

33 See further Federico Fabbrini, Economic Governance in Europe (Oxford: Oxford University Press, 2016).

34 See Armin von Bogdandy, 'The European Union as a Human Rights Organization? Human Rights at the Core of the European Union’ (2000) 37 CML Rev, 1307.
} 
significantly enhanced in order to face new challenges. A major novelty in this regard was represented by the enactment, in 1998, of the 11th Additional Protocol to the ECHR. ${ }^{35}$ This protocol unified the ECommHR and the former ECtHR into a permanent ECtHR, and made the jurisdiction of the latter to hear direct individual applications mandatory for all contracting parties. The possibility for individual applicants to bring proceedings for violations of the ECHR remarkably strengthened the role of the ECtHR. ${ }^{36}$

In this situation, both the CJEU and the ECtHR felt invested with a core function in the protection of human rights in Europe and subsequently collided with each other in an attempt to affirm their position as constitutional courts of a new European supranational public order. ${ }^{37}$ The early signs of a new relationship between the organs of the ECHR and the EU emerged in the $1990 \mathrm{M}$ \& Co. $v$ Germany decision of the ECommHR. ${ }^{38}$ In this case, the ECommHR, while declaring inadmissible a complaint against an EU Member State for acts it had carried out in execution of its EEC obligations, held that the ECHR 'does not prohibit a Member State from transferring powers to international organisations' 39 but made it clear that 'a transfer of powers does not necessarily exclude a State's responsibility under the Convention with regard to the exercise of the transferred power'. ${ }^{40}$ According to the ECommHR, 'the transfer of powers to an international organisation is not incompatible with the Convention provided that within that organisation fundamental rights will receive an equivalent protection'. ${ }^{41}$ As has been argued, this statement suggested that the inadmissibility of the application was not ratione personae but rather ratione materiae, that is, due to the equivalence of the systems for the protection of fundamental rights in the ECHR and in the EU framework. ${ }^{42}$

It was, however, after Opinion 2/94-the CJEU's first judicial pronouncement on the accession of the EU to the ECHR, delivered in $1996^{43}$ - that the relationship between the CJEU and the ECtHR became tenser. The CJEU had been asked by the European Commission to rule on the admissibility of the

\footnotetext{
35 See Alec Stone Sweet and Hellen Keller, 'The Reception of the ECHR in National Legal Orders', in Hellen Keller and Alec Stone Sweet (eds), A Europe of Rights (Oxford: Oxford University Press, 2008) 3, 7.

36 See Alec Stone Sweet, 'Sur la constitutionnalisation de la Convention européenne des droits de l'homme' (2009) 80 Revue trimestrielle des droits de l'homme, 923.

37 Compare Luzius Wildhaber, 'A Constitutional Future for the European Court of Human Rights' (2002) 23 Human Rights Law Journal, 161 (characterizing the ECtHR as a Constitutional Court) with Bo Vesterdorf, 'A Constitutional Court for the EU?' in Ingolf Pernice, Juliane Kokott, and Cheryl Saunders (eds), The Future of the European Judicial System in a Comparative Perspective (Baden-Baden: Nomos, 2006) 83 (characterizing the ECJ as a Constitutional Court).

38 ECommHR, $M$ \& Co. v Germany, no. 13258/87, decision of 9 February 1990.

39 Ibid at para. 8.

${ }^{40}$ Ibid.

${ }^{41}$ Ibid.

42 See Maria Elena Gennusa, 'La CEDU e l'Unione Europea', in Marta Cartabia (ed), I diritti in azione (Bologna: Il Mulino, 2007) 91, 108.

43 Opinion 2/94, ECLI:EU:C:1996:140.
} 
accession of the EC to the ECHR. In a controversial ruling, the CJEU held that accession required an amendment of the EU treaties, since neither Article F EU Treaty nor the implied powers which the EC enjoyed according to Article 308 EC Treaty were sufficient to justify the 'entry of the Community into a distinct international institutional system as well as integration of all the provisions of the [ECHR] into the Community legal order'. ${ }^{44}$ Many scholars, however, have interpreted the decision as a sign of the opposition by the CJEU to admit a review of EC measures by the ECtHR and of the CJEU's fear that it might lose its role of court of last instance in the EU system, including with regard to the protection of fundamental rights. ${ }^{45}$

This has been, otherwise, also the interpretation of the opinion given by the ECtHR. The perceived hostility of the CJEU soon produced a critical reaction by the ECtHR. A first 'warning shot' ${ }^{\prime} 6$ against the CJEU was delivered by the ECtHR in the Cantoni case, ${ }^{47}$ a few months after the opinion of the CJEU. Here the ECtHR had no hesitation in reviewing the complaint of a French citizen against a state law which simply implemented domestically an EC directive. It was in the 1999 Matthews case, ${ }^{48}$ however, decided just after the entry into force of the 11th Additional Protocol to the ECHR, that the ECtHR elaborated in a more comprehensive way a theory for the review of the action of the EU by the ECHR bodies. ${ }^{49}$ The case originated from an application by a British citizen residing in Gibraltar and concerned compatibility with the right to vote (protected by Article 3 Protocol 1 to the ECHR) of the 1976 EC Act establishing the direct election of the European Parliament, but excluding Gibraltar from the suffrage.

The decision pending before the ECtHR concerned the legality of an act of primary EU law, which the United Kingdom had subscribed to as an EU Member State. The ECtHR clarified that 'acts of the EC as such cannot be challenged before the Court because the EC is not a Contracting Party'. 50 Nevertheless, it declared the application admissible holding that 'the Convention does not exclude the transfer of competences to international

\footnotetext{
44 Ibid at para. 34.

45 This interpretation of the decision has been denied, however, by the judges of the CJEU. See, eg Antonio Tizzano, 'La protection des droits fondamentaux en Europe: la Cour de Justice et le juridictions constitutionnelles nationales' (2006) Revue de Droit de l'Union Européenne, 9. See, also, the diplomatic position of the ECtHR judge Egbert Myjer, 'Can the EU Join the ECHRGeneral Conditions and Practical Arrangements', in Pernice, Kokott, and Saunders (n 37) 297 (who summarizes the history of the relationship between the ECJ and the ECtHR without mentioning Opinion 2/94 by the ECJ).

46 Dean Spielmann, 'Human Rights Case Law in the Strasbourg and Luxembourg Courts: Conflicts, Inconsistencies and Complementarities', in Alston (n 2) 764.

47 Application no 17862/91, Cantoni v France, ECLI:CE:ECHR:1996:1115JUD001786291.

48 Application no. 24833/94, Matthews v UK, ECLI:CE:ECHR:1999:0218JUD002483394.

49 See Iris Canor, 'Primus Inter Pares: Who is the Ultimate Guardian of Fundamental Rights in Europe?’ (2000) 25 EL Rev, 3.

50 Matthews (n 48) at para. 32.
} 
organisations provided that Convention rights continue to be "secured". Member States' responsibility therefore continues even after such a transfer. ${ }^{.51}$ In addition, the ECtHR underlined how the contested act '[could] not be challenged before the European Court of Justice for the very reason that it [was] not a "normal" act of the Community, but [it was] a treaty within the Community legal order ${ }^{52}$ and therefore undertook a detailed examination of the merit of the complaint, reaching the conclusion that in the circumstances of the present case, the very essence of the applicant's right to vote, as guaranteed by Article 3 of Protocol No. 1 ECHR, was denied. ${ }^{53}$

The implications of the Matthews decision have been the object of lively debate. While several authors argued that the ruling of the ECtHR introduced a limited ECHR review exclusively for those EC/EU acts which had the status of international treaties in the EU legal order, or, more generically, all the EC/EU acts which could not be reviewed by the CJEU, ${ }^{54}$ other academics argued instead that Matthews resulted in an indirect annexing of the EC/EU into the ECHR system via the EU Member States. ${ }^{55}$ Be that as it may, it is clear, nevertheless, that the decision of the ECtHR represented a fundamental step towards the idea that (some of) the legal acts of the EC/EU could be subject to review for compatibility with the ECHR. ${ }^{56}$ As has been argued, the Matthews decision reflected 'the opinion that rules of Community Law should be in accordance with the European Convention on Human Rights... [and] that it belongs to the task of the Human Rights Court to supervise the proper application of the Convention also by the Community, ${ }^{57}$ if necessary by invoking the responsibility of the EC Member States.

The subsequent case law of the ECtHR, however, has not offered further opportunities to explore the implications of the Matthews doctrine. Mainly for procedural reasons, the ECtHR has rejected all the complaints raised against the EU or its Member States jointly or severally. For instance, in the Segi case, the ECtHR rejected the application because the plaintiffs had not demonstrated themselves to be victims of a violation of the ECHR rights; ${ }^{8}$ and in Senator Lines, because the violation had been remedied by the $\mathrm{EU}$ institutions before the

51 Ibid at para. 32 .

52 Ibid at para. 33.

53 Ibid at para. 65.

54 See Koen Lenaerts, 'Respect for Fundamental Rights as a Constitutional Principle of the European Union' (2000) 6 Columbia Journal of European Law, 1, 15.

55 See eg Laurent Scheeck, 'Solving Europe's Binary Human Rights Puzzle: The Interaction Between Supranational Courts as a Parameter of European Governance' (2005) 15 Questions de recherche de Science Po, 1, 33.

56 Canor (n 49) 4.

57 Schermers (n 22) 681.

58 Application nos 6422/02 \& 9916/02, Segi e Gestoras Pro Amnistia v the (then) 15 States of the EU, ECLI:CE:ECHR:2002:0523DEC000642202. 
decision of the ECtHR. ${ }^{59}$ Nevertheless, as several instances of such " spontaneous" coordination' 60 between the case law of the CJEU and of the ECtHR highlight, it appears that the two supranational courts soon understood the perilous consequences, in terms of legitimacy and effectiveness, of a protracted confrontation, ${ }^{61}$ and gradually moved toward a form of mutually beneficial entente cordiale. ${ }^{62}$

\section{The phase of comity}

At the beginning of the twenty-first century a set of unprecedented transformations took place within the framework of the EU, ${ }^{63}$ with significant effects on the relationship between the CJEU and the ECtHR. In view of the EU enlargement toward the new democracies of Central and Eastern Europe and in the awareness of the need to overcome the institutional ambiguities left open by the EU Treaty, the Member States and the EU institutions inaugurated with the Laeken Declaration of 2001 a process of constitutional reform aimed at clarifying the identity, the finality, and the future institutional architecture of the EU, also with a view to bringing the EU closer to its citizens. Through the work of two Constitutional Conventions-composed of representatives of the EU institutions, of the Member States, and of civil society-the EU formally proclaimed in 2000 a Charter of Fundamental Rights and in 2004 a Treaty establishing a Constitution for Europe (in which the Charter was incorporated) was presented for ratification by the Member States. ${ }^{64}$

Despite the many difficulties which arose during this process of constitutional self-definition-exemplified, on the one hand, by the initial reticence of the Member States to grant legal value to the Charter ${ }^{65}$ and, on the other hand, by the failure of the ratification of the Constitutional Treaty in several member states in 2005-most of the novelties advanced during the 2000s found shelter in the Lisbon Treaty. ${ }^{66}$ This Treaty, which was adopted to 'salvage' the content of the Constitutional Treaty, ${ }^{67}$ was itself under peril for some time. But

\footnotetext{
59 Application no 56672/00, Senator Lines Gmbh $v$ the (then) 15 States of the EU, ECLI:CE:ECHR:2004:0310DEC005667200.

60 Gennusa (n 42) 115.

61 Spielmann (n 46) 757; Canor (n 49) 20.

62 See Lech Garlicki, 'Cooperation of Courts: The Role of Supranational Jurisdictions in Europe' (2008) 6 International Journal Constitutional Law, 509.

63 See generally Joseph Weiler and Marlene Wind (eds), European Constitutionalism Beyond the State (Cambridge: Cambridge University Press, 2003).

64 See Michel Rosenfeld, 'The European Convention and Constitution Making in Philadelphia' (2003) 1 International Journal Constitutional Law, 373.

65 As it is well known, EU courts gradually began to use the Charter of Fundamental Rights as a benchmark in their human rights jurisprudence. See Case T-54/99, max.mobil, ECLI:EU:T:2002:20; Case C-540/03, Parliament v Council, ECLI:EU:C:2006:429.

66 See Jean-Claude Piris, The Lisbon Treaty: A Legal and Political Analysis (Cambridge: Cambridge University Press, 2010) 48.

67 Bruno de Witte, 'Saving the Constitution? The Escape Routes and their Legal Feasibility' in Giuliano Amato, Hervé Bribosia, and Bruno de Witte (eds), Genesis and Destiny of the European Constitution (Brussels: Bruylant, 2007) 919.
} 
eventually, it entered into force on 1 December 2009 bringing about a significant overhaul in the structure of the EU and in its system for the protection of fundamental rights in the EU. ${ }^{68}$ The new Article $6 \mathrm{EU}$ Treaty, in particular, today grants legal value to the Charter as part and parcel of the EU's primary law, and, importantly, mandates the accession of the EU to the ECHR.

These major constitutional transformations in the EU system form the background to the evolution of the jurisprudence of the two European supranational courts. ${ }^{69}$ Boosted by the hermeneutical value of the EU Charter of Fundamental Rights, the CJEU has delivered in the last decade a series of remarkable decisions on human dignity ${ }^{70}$ non-discrimination on the basis of gender ${ }^{71}$ or sexual orientation, ${ }^{72}$ freedom of expression, ${ }^{73}$ social rights, ${ }^{74}$ and political entitlements. ${ }^{75}$ Particularly brave in light of the international scenario has then been the case law of the CJEU protecting due process rights in the field of counterterrorism. ${ }^{76}$ As noted by Marta Cartabia, the 'EU judiciary experimented here its capacity of being rigorous in the protection of rights in one of the most thorny fields, given the fact that the seriousness of the international situation tends to attenuate the sensitiveness toward the rights of the suspected terrorist and produces a stronger propensity toward the demand for security rather than towards that for liberty and justice'. ${ }^{77}$

${ }^{68}$ See Lucia Serena Rossi, 'How Fundamental Are Fundamental Principles? Primacy and Fundamental Rights after Lisbon' (2008) 27 Yearbook of European Law, 65; and Emmanuelle Bribosia, 'L'avenir de la protection de droits fondamentaux dans l'Unione européenne', in Amato, Bribosia and de Witte (n 67) 995.

${ }^{69}$ Douglas-Scott (n 12) 661.

70 See Case C-36/02, Omega, ECLI:EU:C:2004:614 (recognizing a fundamental right to dignity as a justification for the limitation of the freedom of movement of goods).

${ }^{71}$ See e.g Case C-285/98, Kreil, ECLI:EU:C:2000:2 (declaring incompatible with EU law a provision of the German Constitution prohibiting women from serving in the military); Case C-46/07, Commission v Italy, ECLI:EU:C:2008:618 (declaring incompatible with EU law a provision of the Italian social security legislation setting up a different retirement age for men and women).

72 See eg Case C-117/01, K.B., ECLI:EU:C:2004:7 (recognizing the right of transsexuals); Case C423/04, Richards, ECLI:EU:C:2006:256 (idem).

${ }^{73}$ See eg Case C-112/00, Schmidberger, ECLI:EU:C:2003:333 (recognizing the right to freedom of expression as a justification for the restriction of the freedom of movement); Case C-380/05, Centro Europa 7, ECLI:EU:C:2008:59 (declaring incompatible with EU law a provision of the Italian media law which did not ensure pluralism in the broadcasting system).

${ }^{74}$ See eg Case C-184/99, Grzelczyk, ECLI:EU:C:2001:458 (recognizing the right of migrant students to obtain social security benefits in the host state); Case C-438/05, Viking, ECLI:EU:C:2007:772 (recognizing a fundamental right to strike).

75 See eg Case C-300/04, Eman \& Sevinger (Aruba), ECLI:EU:C:2006:545 (holding a Dutch law restricting the franchise to the EU Parliament of Dutch citizens residing in Aruba incompatible with EU law).

${ }^{76}$ See Federico Fabbrini, 'The Role of the Judiciary in Times of Emergency: Judicial Review of Counter-Terrorism Measures in the United States Supreme Court and the European Court of Justice' (2009) 28 Yearbook of European Law, 664.

77 Cartabia (n 20) 51. 
Given the growing attention toward the protection of fundamental rights both in the primary law of the EU, ${ }^{78}$ and in the case law of the CJEU, ${ }^{79}$ it is perhaps possible to explain why, in 2005, the ECtHR decided to take a step back with respect to its Matthews doctrine. ${ }^{80}$ Waiting for the political process to accomplish the formal accession of the EU to the ECHR, the ECtHR, in the Bosphorus case, ${ }^{81}$ reserved for itself the power to review indirectly the legality of the acts of the EU through the review of the states implementing measures only in specific and quasi-hypothetical cases. ${ }^{82}$ The Bosphorus case concerned a controversy dating back to the 1990 s on which the CJEU had already had the chance to rule. ${ }^{83}$ The applicant, a Turkish airline company which had leased a Yugoslavian aircraft, complained that its right to property had been unreasonably limited by the decision of the Irish authorities to impound the aircraft in the implementation of an EC regulation which in turn gave effect in the EU to a UN Security Council resolution adopted to stop the war in (former) Yugoslavia.

In its ruling, the ECtHR recognized that the interference with the applicant's right to property 'was not the result of an exercise of discretion by the Irish authorities, either under Community or Irish law, but rather amounted to compliance by the Irish State with its legal obligations flowing from Community law.' ${ }^{84}$ As in Matthews and other previous decisions, however, the ECtHR found itself competent to rule on the matter, arguing that, if 'the ECHR does not, on the one hand, prohibit Contracting Parties from transferring sovereign power to an international (including a supranational) organisation in order to pursue cooperation in certain fields of activity', 85 'on the other hand, it has also been accepted that a Contracting Party is responsible under Article 1 ECHR for all acts and omissions of its organs regardless of whether the act or omission in question was a consequence of domestic law or of the necessity to comply with international legal obligations' ${ }^{86}$

\footnotetext{
78 See Koen Lenaerts and Eddy de Smijter, 'The Charter and the Role of the European Courts' (2001) 8 Maastricht Journal of European and Comparative Law, 90.

79 See Leonard Besselink, The Protection of Fundamental Rights Post-Lisbon: The Interaction Between the EU Charter of Fundamental Rights, the ECHR and National Constitutions, General Report of the FIDE Congress, Tallinn, 30-31 May 2012, 42.

80 See Steve Peers, 'Case Note: Bosphorus' (2006) 2 European Constitutional Law Review, 442, 452; Sionaidh Douglas-Scott, 'Case Note: Bosphorus' (2006) 43 CML Rev, 243, 249.

81 Application no 45036/98, Bosphorus v Ireland, ECLI:CE:ECHR:2005:0630JUD004503698.

82 Garlicki (n 62) 528.

83 Case C-84/95, Bosphorus, ECLI:EU:C:1996:312; on which see Iris Canor, "Can Two Walk Together Except They Be Agreed"? The Relationship Between International Law and European Law: The Incorporation of United Nations Sanctions Against Yugoslavia into European Community Law through the Perspective of the European Court of Justice' (1998) 35 CML Rev, 137.

84 Bosphorus (n 81) at para. 148.

85 Ibid at para. 152.

86 Ibid at para. 153.
} 
Nevertheless, in reconciling these two opposing positions and in deciding 'the extent to which a State's action can be justified by its compliance with obligations flowing from its membership of an international organization', 87 the ECtHR advanced a new approach, oriented toward emphasizing the selfsufficiency of the EU system for the protection of fundamental rights rather than the role of external supervision exercised by the ECHR organs. According to the ECtHR, in fact, 'State action taken in compliance with such legal obligations is justified as long as the relevant organisation is considered to protect fundamental rights, as regards both the substantive guarantees offered and the mechanisms controlling their observance, in a manner which can be considered at least equivalent to that for which the Convention provides' ${ }^{88}$ Refining a reasoning that was in nuce already in $M \&$ co., the ECtHR thus held that, as long as the protection of fundamental rights in the $\mathrm{EU}$ is presumptively equivalent to that of the ECHR, the acts of the Member States which simply implement EU measures at the domestic level will not be reviewed by the ECtHR. ${ }^{89}$

In the end, the Bosphorus decision represents a partial withdrawal from the previous position of the ECtHR concerning the possibility to review the legal acts of the EU via a review of the States' implementing measures. ${ }^{90}$ In order to prevent serious gaps in the protection of fundamental rights in the European multi-level system, the ECtHR clarified that the presumption of equivalence between the EU system for the protection of fundamental rights and the ECHR 'can be rebutted if, in the circumstances of a particular case, it is considered that the protection of Convention rights was manifestly deficient. In such cases, the interest of international cooperation would be outweighed by the Convention's role as a "constitutional instrument of European public order" in the field of human rights'. ${ }^{91}$ Nevertheless, as demonstrated by subsequent cases, ${ }^{92}$ this

87 Ibid at para. 154 .

88 Ibid at para. 155.

89 See Nikolaos Lavranos, 'Towards a Solange-Method Between International Courts and Tribunals?', in Tom Broude and Yuval Shany (eds), The Shifting Allocation of Authority in International Law: Considering Sovereignty, Supremacy and Subsidiarity (Oxford: Hart Publishing, 2008) 217.

90 See Annalisa Ciampi, 'L’Union européenne et le respect des droits de l'homme dans la mise en oeuvre des sanctions devant la Cour européenne des droits de l'homme' (2006) 110 Revue Générale de Droit International Public, 114. See in this regard also the joint concurring opinion to the Bosphorus decision by the Judges Rozakis, Tulkens, Traja, Botoucharova, Zagrebelsky, and Garlicki, who expressed their being perplexed as to the decision of the majority arguing at para. 3 that 'for the Court to leave to the Community's judicial system the task of ensuring "equivalent protection", without retaining a means of verifying on a case-by-case basis that that protection is indeed "equivalent", would be tantamount to consenting tacitly to substitution, in the field of Community law, of Convention standards by a Community standard which might be inspired by Convention standards but whose equivalence with the latter would no longer be subject to authorised scrutiny'.

91 Bosphorus (n 81) at para. 156, quoting Application no 15318/89, Loizidou $v$ Turkey, ECLI:CE:ECHR:1996:1218JUD001531889.

92 See Application n. 16931/04, Coopérative des agriculteurs de Mayenne $v$ France, ECLI:CE:ECHR:2006:1010DEC001693104; Application no 13645/05, Cooperatieve Producentenirganisatie v Netherland, ECLI:CE:ECHR:2009:0120DEC001364505. 
statement of the ECtHR was not meant to be a real threat against the EU: rather, it is the expression of a form of comity vis-à-vis the CJEU, reflecting a faith in the capacity of the latter to ensure effective protection of human rights in the EU. ${ }^{93}$

\section{The present: accession denied}

This section of the article examines the current status of the relations between the CJEU and the ECtHR, departing from the obligation enshrined in the postLisbon EU treaties for the EU to accede to the ECHR, and focusing on the recent Opinion 2/13, with which CJEU has declared invalid the draft accession agreement of the EU to the ECHR. In fact, after 60 years of informal judicial interactions, legal changes both in the EU and ECHR systems created the conditions for more formalized relations between the CJEU and the ECHR. ${ }^{94}$ On the one hand, ECHR Protocol No. 14-adopted in 2004, and entered into force in $2010^{95}$-added a new paragraph to Article 59 ECHR according to which ' $[\mathrm{t}]$ he European Union may accede to this Convention'. ${ }^{96}$ On the other hand, the Lisbon Treaty-concluded in 2007, and entered into force in 2009-modified Article 6 TEU, enshrining the rule that the "Union shall accede to the European Convention for the Protection of Human Rights and Fundamental Freedoms, ${ }^{97}$ albeit subject to a number of precise conditions enunciated in Protocol No. 8, attached to the EU treaties.

In order to operationalize accession, in May 2010 the Committee of Ministers of the Council of Europe was mandated to prepare, together with representatives of the European Commission, a draft agreement on the accession of the EU to the ECHR. ${ }^{98}$ In this context, as an instance of direct judicial dialogue, delegations from the CJEU and ECtHR organized a series of meetings amongst their respective members, resulting in a joint declaration by the Presidents of the two European courts of January 2011. ${ }^{99}$ Following a series of meetings of the

\footnotetext{
93 See Yuval Shany, The Competing Jurisdictions of International Courts and Tribunals (Oxford: Oxford University Press, 2003) (discussing ideas of judicial comity).

94 See Jean Paul Jacqué, 'The Accession of the European Union to the European Convention on Human Rights and Fundamental Freedoms' (2011) 48 CMLRev, 995 and Tobias Lock, 'Walking on a Tightrope: the Draft Accession Agreement and the Autonomy of the EU Legal Order' (2011) 48 CMLRev.

95 Art. 19, Protocol No. 14 to the ECHR.

96 Art. 17, Protocol No. 14 to the ECHR, now Art. 59(2) ECHR.

97 Art. 6(2) TEU.

$98 \mathrm{CM} / \operatorname{Del} / \operatorname{Dec}(2010) 1085,26$ May 2010.

99 Joint communication from Presidents Costa and Skouris, Luxembourg, 17 January 2011, http:// curia.europa.eu/jcms/upload/docs/application/pdf/2011-02/cedh_cjue_english.pdf (last accessed 18 February 2016).
} 
informal working group called 'CDDH-UE', a first draft accession agreement was published on 19 July 2011. ${ }^{100}$ With some minor changes, these legal instruments were transmitted with a report to the Committee of Ministers in October 2011. ${ }^{101}$ However, the Committee of Ministers mandated to the $\mathrm{CDDH}$ to continue its negotiations with the $\mathrm{EU}$ in an ad hoc group called ' $47+1$ '. ${ }^{102}$ These negotiations resulted in the elaboration of a set of additional documents surrounding the accession process, including amongst others an EU declaration and a draft for memoranda of understanding to be concluded between the EU and other non-EU members of the ECHR which have a close relationship with the EU. This package of instruments was compiled in the Final Report to the CDDH of 5 April 2013. ${ }^{103}$

In July 2013, the draft Accession Agreement of the EU to the ECHR was referred by the Commission to the CJEU for an ex ante review of its compatibility with the EU treaties, pursuant to Article 218(11) TFEU. However, in its Opinion 2/13, delivered on 18 December 2014, the CJEU ruled that the draft accession agreement was incompatible with the EU treaties. Just as had happened in 1996 with Opinion 2/94, therefore, the CJEU brought to a halt both the process of accession of the EU to the ECHR, and with it the prospect of a new, formalized relationship between the ECtHR and the CJEU itself. The terms of the draft accession agreement of the EU to the ECHR, and the judicial response of the CJEU in Opinion 2/13 are hereafter analysed, in order to appreciate the nature of the current relations between the CJEU and the $\mathrm{ECtHR}$, and thus set the ground for a discussion about possible future interactions between the two European supranational courts.

\section{A. The draft accession agreement of the EU to the ECHR}

The draft agreement disclosed in April 2013 sought to articulate the ways and means of EU accession to the ECHR. The preamble of the draft agreement

\footnotetext{
100 The agreement is contained in 8th Working meeting of the $\mathrm{CDDH}$ informal working group on the accession of the European Union to the European Convention on Human Rights (CDDH-UE) with the European Commission, Draft legal instruments on the accession of the European Union to the European Convention on Human Rights, Strasbourg, 19 July 2011, CdDH-UE(2011)16 Final version, <http://www.coe.int/t/dghl/standardsetting/hrpolicy/Accession/Working_documents/ CDDH-UE_2011_16_final_en.pdf> (last accessed 18 February 2016).

101 Steering Committee for Human Rights (CDDH), Report to the Committee of Ministers on the elaboration of legal instruments for the accession of the European Union to the European Convention on Human Rights, Strasbourg, 14 October 2011, CDDH(2011)009, <http://www. coe.int/t/dghl/standardsetting/hrpolicy/Accession/Meeting_reports/CDDH_2011_009_en.pdf > (last accessed 18 February 2016).

$102 \mathrm{CM} / \operatorname{Del} / \operatorname{Dec}(2012) 1145 / 4.5,13$ June 2012.

${ }^{103}$ Fifth Negotiation meeting between the CDDH ad hoc negotiation group and the European Commission on the accession of the European Union to the European Convention on Human Rights, Final Report to the CDDH, Strasbourg, 5 April 2013, 47+1(2013)008. The version of the draft accession agreement contained therein will be referred to here (hereinafter: 'Draft Accession Agreement').
} 
recalled that the 'European Union is founded on the respect for human rights and fundamental freedoms' and proclaimed that the EU's accession 'will enhance coherence in human rights protection in Europe'. Moreover, while 'any person, non-governmental organization or group of individuals should have the right to submit the acts, measures or omissions of the European Union to the external control of the European Court of Human Rights', the draft also acknowledged that 'having regard to the specific legal order of the European Union, which is not a State, its accession requires certain adjustments to the Convention system to be made by common agreement'. ${ }^{104}$ These adjustments were subsequently set out in the operative part.

On the basis of Article 1(1) of the draft accession agreement, the EU would have acceded not only to the ECHR, but also to its Protocols No. 1 and No. $6,{ }^{105}$ which are the two protocols that have been ratified by all the EU Member States. ${ }^{106}$ The agreement furthermore would have amended the ECHR to accommodate EU membership. In addition, the draft agreement clarified the application of certain terms in the ECHR and its protocols referring 'more generally to the concept of 'State' or to certain elements thereof. ${ }^{107}$ These include, among others, 'national security', 'national law', 'life of the nation', and 'territorial integrity'.

Institutionally, the most prominent feature of the agreement was the 'corespondent mechanism' set out in Article 3, which also addressed the socalled 'prior involvement' of the CJEU. Under the co-respondent mechanism, the EU and one or more of its Member States become parallel parties to a dispute. ${ }^{108}$ This was considered necessary in order 'to accommodate the specific situation of the EU as a non-State entity with an autonomous legal system that is becoming a Party to the Convention alongside its own member States'. ${ }^{109}$ More precisely, the explanatory report stressed the 'special feature of the EU legal system that acts adopted by its institutions may be implemented by its member States and, conversely, that provisions of the EU founding treaties agreed upon by its member States may be implemented by institutions, bodies, offices or agencies of the EU'. ${ }^{110}$ Consequently, following accession, there could arise the unique situation in the Convention system in which a legal act is enacted by one High Contracting Party and implemented by another'. ${ }^{111}$ To take into account the 'unique situation' of the EU, however, the

\footnotetext{
104 Preamble, Draft Accession Agreement.

105 Art. 1(1) Draft Accession Agreement.

106 Robert Uerpmann-Wittzack, 'Rechtsfragen und Rechtsfolgendes Beitritts der Europäischen Union zur EMRK' (2012) Europarecht (Beiheft 2), 167, 168.

107 Final Report to the CDDH, Draft explanatory report, 20 (pt 28).

108 Art. 3(1) Draft Accession Agreement amending Art. 36 of the ECHR.

109 Final Report to the CDDH, Draft explanatory report, 22 (pt 38).

110 Ibid.

111 Ibid.
} 
draft accession agreement also introduced a special privilege for the CJEU through a brand new institutional device: the prior involvement mechanism.

The draft agreement envisaged two situations. On the one hand, the Member States of the EU could become co-respondents where there is a compatibility issue between the ECHR and EU primary law, 'notably where that violation could have been avoided only by disregarding an obligation under' EU primary law. ${ }^{112}$ This is the situation the ECtHR faced in Matthews. The EU or its Member States can only become co-respondents by accepting an invitation to that effect from the ECtHR or at their own request with the subsequent decision by the ECtHR 113 since, as the CDDH report put it, "[n]o High Contracting Party may be compelled against its will to become a co-respondent'. ${ }^{114}$ Vice versa, when an application is lodged against both the EU and one or more of its Member States, their status can be changed upon their request to that of corespondent under the same procedure. ${ }^{115}$

On the other hand, in cases in which one or more EU Member State is a respondent, the EU could become a co-respondent where there is an issue of compatibility between the rights guaranteed by the ECHR and a provision of EU secondary law, 'notably where that violation could have been avoided only by disregarding an obligation under European Union Law'. ${ }^{116}$ This is the situation epitomized by the Bosphorus case. In this case, the CJEU would be afforded the special opportunity to assess the compatibility of the contested provision with the rights as guaranteed under the ECHR, if it had not done so already. ${ }^{117}$ As the explanatory report clarifies, preliminary reference proceedings under EU law, ${ }^{118}$ which would represent such an opportunity, do not constitute a legal remedy that has to be exhausted by applicants before they can turn to the ECtHR. ${ }^{119}$ Through the prior involvement mechanism, however, the CJEU was given the chance to review the legality of EU law when the case is brought before the ECtHR. Although the explanatory report states that 'this situation is expected to arise rarely', ${ }^{120}$ no court in the other Contracting Parties to the ECHR enjoys any comparable privilege.

Under the draft accession agreement, if the ECtHR found a violation in a case where the co-respondent mechanism is applied, 'the respondent and the corespondent shall be jointly responsible for that violation, unless the Court, on

112 Art. 3(3) Draft Accession Agreement, which refers specifically to the TEU, TFEU 'or any other provision having the same legal value pursuant to those instruments'. The explanatory report refers to 'primary law', Final Report to the CDDH, Draft explanatory report, 24 (pt 49).

113 Art. 3(5) Draft Accession Agreement.

${ }^{114}$ Final Report to the CDDH, Draft explanatory report, 25 (pt 53).

115 Art. 3(4) Draft Accession Agreement.

116 Art. 3(2) Draft Accession Agreement.

117 Art. 3(6) Draft Accession Agreement.

118 Art. 267 TFEU.

119 Final Report to the CDDH, Draft explanatory report, 27 (pt 65).

${ }^{120}$ Final Report to the CDDH, Draft explanatory report, 27 (pt 66). 
the basis of the reasons given by the respondent and the co-respondent, and having sought the views of the applicant, decides that only one of them be held responsible'. ${ }^{121}$ According to the explanatory report, 'the respondent and the corespondent(s) are normally held jointly responsible'. ${ }^{122}$ By way of exception, allocating responsibility to only the respondent or co-respondent must be made 'on the basis of the reasons given by the respondent and the co-respondent, and having sought the views of the applicant', as otherwise, according to the report, '[a]pportioning responsibility separately to the respondent and the co-respondent(s) on any other basis would entail the risk that the Court would assess the distribution of competences between the EU and its member States'. ${ }^{123}$ This, after all, remains the sole prerogative of the CJEU. ${ }^{124}$

Article 5 of the draft accession agreement stated that the proceedings before the CJEU 'shall be understood constituting neither procedures of international investigation [n] or settlement' in the meaning of the ECHR. ${ }^{125}$ This provision sought to address the long-standing self-image of the CJEU as the supreme court of a 'new legal order', 126 establishing a 'Community based on the rule of law' endowed with a 'constitutional charter'127 and equipped with a 'complete system of legal remedies'. ${ }^{128}$ As the CJEU concisely put it in its Opinion $1 / 91$, 'the [EU] Treaty, albeit concluded in the form of an international agreement, none the less constitutes the constitutional charter of a Community based on the rule of law'. ${ }^{129}$

Finally, provisions ware also made in the draft accession agreement to accommodate the position of the EU as a partial member of the CoE. Under Article 6, the European Parliament would send a delegation to the Parliamentary Assembly of the $\mathrm{CoE}$ to participate and vote as regards the election of judges of the ECtHR. ${ }^{130}$ Moreover, according to Article 7, the EU could participate and vote in the Committee of Ministers of the $\mathrm{CoE}$ as regards the ECHR. ${ }^{131}$ However, the agreement emphasized that the parallel presence of representatives of the EU and the Member States in the Committee of Ministers 'shall not prejudice the effective exercise by the Committee of Ministers of its supervisory

\footnotetext{
121 Art. 3(7) Draft Accession Agreement.

122 Final Report to the CDDH, Draft explanatory report, 26 (pt 62).

123 Final Report to the CDDH, Draft explanatory report, 26 (pt 62).

124 Art. 19(1) TEU (stating that the CJEU 'shall ensure that in the interpretation and application of the Treaties the law is observed') and Art. 344 TFEU (stipulating the exclusive jurisdiction of the CJEU in matters relating to EU law by barring Member States from using other methods of dispute settlement); further Gragl (n 5) 19-30.

125 Art. 5 Draft Accession Agreement.

126 Case 26/62, van Gend en Loos, ECLI:EU:C:1963:1, para. 10.

127 Case 294/83, Parti écologiste “Les Verts", ECLI:EU:C:1986:166, para. 23.

128 Ibid.

129 Opinion 1/91, ECLI:EU:C:1991:490, para. 21.

130 Art. 6(1) Draft Accession Agreement.

131 Art. 7(2) Draft Accession Agreement.
} 
functions' under the ECHR. ${ }^{132}$ Finally, the EU would also contribute to the expenditure related to the operation of the ECHR, ${ }^{133}$ and 'shall, within the limits of its competences, respect' certain provisions from relevant related agreements in the context of the ECHR and the CoE. ${ }^{134}$

In sum, this 'quasi-accession' to the $\mathrm{CoE}$ and the ECHR, was deemed preferable to going through the 'cumbersome procedure' of actually amending all relevant agreements to accommodate the EU. ${ }^{135}$ Generally, accession was to be achieved while maintaining the ECHR system 'by making only those adaptations that are strictly necessary. ${ }^{136}$ Arguably the most significant of these adaptations is the prior involvement mechanism of the CJEU, which would have allowed the CJEU to adjudicate a case once it is already pending before the ECtHR. Even though only devised for exceptional use, it elevated the case law of the CJEU, making it a more prominent reference point than ever for the ECtHR. The draft accession agreement would thus have attributed to the CJEU a position no other constitutional court among the Contracting Parties enjoys-namely to assess cases before the ECtHR gets a chance. ${ }^{137}$ Although this feature of the draft accession agreement was mostly regarded by observers as sufficient to win the support of the CJEU for accession, ${ }^{138}$ in Opinion 2/13 the CJEU ruled otherwise.

\section{B. Opinion $2 / 13$}

The draft accession agreement of the EU to the ECHR was referred by the European Commission to the CJEU in July 2013, with a view to confirming its legality. In its Opinion 2/13, delivered on 18 December 2014, however, the CJEU acting as a Full Court ruled that the draft accession agreement of the EU to the ECHR was incompatible with the EU treaties. ${ }^{139}$ The CJEU began its opinion by sketching the institutional framework of the ECHR system, ${ }^{140}$ and summarizing the evolving relationship between the EU and the ECHR. ${ }^{141}$ In this regard, the CJEU stressed how it had historically drawn inspiration from the ECHR in building its human rights jurisprudence, ${ }^{142}$ recalled that in Opinion $2 / 94$ it had found that the EU had lacked the competences to accede to the

132 Art. 7(4) Draft Accession Agreement. See also Arts 39 and 46 ECHR.

133 Art. 8 Draft Accession Agreement.

${ }^{134}$ Art. 9(1) Draft Accession Agreement. This includes, for instance, parts of the General Agreement on Privileges and Immunities of the Council of Europe of 2 September 1949.

${ }_{135}$ Final Report to the CDDH, Draft explanatory report, 35 (pt 101).

136 Final Report to the CDDH, Draft explanatory report, 17 (pt 7).

137 See Aida Torres Pérez, 'Too Many Voices? The Prior Involvement of the Court of Justice of the European Union' in Vasiliki Kosta, Nikos Skoutaris, and Vassilis Tzevelekos (eds), The EU Accession to the ECHR (Oxford: Hart Publishing, 2014) 29.

138 Paul Gragl, 'A Giant Leap for European Human Rights? The Final Agreement on The European Union's Accession to the European Convention on Human Rights' (2014) 51 CML Rev, 13, 47.

139 Opinion 2/13 (n 1).

$140 \mathrm{Ibid}$ at para. 3-36.

${ }_{141}$ Ibid at para. 37-45.

142 Ibid at para. 37. 
ECHR, ${ }^{143}$ and mentioned how the Lisbon Treaty now required EU accession to the ECHR - albeit subject to a number of conditions. ${ }^{144}$ The CJEU then summarized the process of accession, ${ }^{145}$ and described the content of the draft accession agreement. ${ }^{146}$

As the CJEU acknowledged, the compatibility of the accession agreement with EU primary law had been endorsed (albeit with sometimes diverging legal arguments) both by the European Commission in its request for an Opinion, ${ }^{147}$ as well as by an exceptionally high number of intervening parties-the Council, the European Parliament, and 24 Member States' governments. ${ }^{148}$ Nevertheless, the CJEU reached a different conclusion. While the CJEU held that the request for an ex ante opinion on the legality of the draft accession agreement was certainly admissible-emphasizing that a possible decision 'after the conclusion of an international agreement binding upon the EU, to the effect that such an agreement is, by reason either of its content or of the procedure adopted for its conclusion, incompatible with the provisions of the Treaties could not fail to provoke, not only in the internal EU context, but also in that of international relations, serious difficulties and might give rise to adverse consequences for all interested parties, including third countries' ${ }^{149}$ — it ruled that the draft accession agreement was substantively incompatible with the EU treaties for at least five reasons. ${ }^{150}$

As a preliminary matter, the CJEU underlined several 'specific characteristics' 151 of the EU legal order which were relevant in assessing the legality of the accession agreement. ${ }^{152}$ On the one hand, the CJEU noted that 'unlike the position under Community law in force when the Court delivered Opinion 2/94, the accession of the EU to the ECHR has, since the entry into force of the Treaty of Lisbon, had a specific legal basis in the form of Article 6 TEU'. ${ }^{153} \mathrm{On}$ the other hand, the CJEU clarified that this did not mean that accession would be rubber-stamped. The CJEU pointed out in this respect that the fact that 'that the EU has a new kind of legal order, the nature of which is peculiar to the EU, its own constitutional framework and founding principles, a particularly sophisticated institutional structure and a full set of legal rules to ensure its operation, has consequences as regards the procedure for and conditions of accession to the ECHR'. ${ }^{154}$ According to the CJEU, the treaties as 'the basic constitutional

143 Ibid at para. 38.

144 Ibid at para. 40-43.

$145 \mathrm{Ibid}$ at para. 46-48.

$146 \mathrm{Ibid}$ at para. 49-70.

147 Ibid at para. 71-107.

148 Ibid at para. 108-143.

$149 \mathrm{Ibid}$ at para. 146.

150 Ibid at para. 153-257.

${ }^{151} \mathrm{Ibid}$ at para. 164.

152 Ibid at para. 153-177.

153 Ibid at para. 153.

154 Ibid at para. 158. 
charter' of the EU, ${ }^{155}$ are characterized by peculiar provisions 'relating to the constitutional structure of the EU, which is seen in the principle of conferral of powers referred to in Articles 4(1) TEU and 5(1) and (2) TEU, and in the institutional framework established in Articles 13 TEU to 19 TEU'.156 Moreover, citing its earlier landmark rulings in van Gen \& Loos, and Costal $E N E L$, the CJEU held that another characteristic arose 'from the very nature of EU law. In particular,... EU law is characterised by the fact that it stems from an independent source of law, the Treaties, by its primacy over the laws of the Member States ..., and by the direct effect of a whole series of provisions which are applicable to their nationals and to the Member States themselves...' 157

As the CJEU further pointed out, "[t] hese essential characteristics of EU law have given rise to a structured network of principles, rules and mutually interdependent legal relations linking the EU and its Member States, and its Member States with each other, which are now engaged... in a "process of creating an ever closer union among the peoples of Europe"'. ${ }^{158}$ According to the CJEU, at the same time, 'at the heart of th [e EU] legal structure'159 is the protection of fundamental rights, now recognized in the EU Charter of Fundamental Rights, which — as clarified in Fransson - binds not only the EU institutions, bodies, and agencies, but also the Member States when they are acting within the scope of EU law. ${ }^{160}$ Finally, the CJEU stressed that '[i]n order to ensure that the specific characteristics and the autonomy of that legal order are preserved, the Treaties have established a judicial system intended to ensure consistency and uniformity in the interpretation of EU law'. ${ }^{161}$ In this regard, it praised the role of the preliminary reference procedure, holding that Article 267 TFEU, 'by setting up a dialogue between one court and another, specifically between the [CJEU] and the courts and tribunals of the Member States, has the object of securing uniform interpretation of EU law ... thereby serving to ensure its consistency, its full effect and its autonomy as well as, ultimately, the particular nature of the law established by the Treaties'. ${ }^{162}$

Based on these preliminary considerations, the CJEU addressed the compatibility of the draft accession agreement with EU primary law, focusing in particular on five aspects. To begin with, the CJEU examined whether the draft accession agreement respected 'the specific characteristics and the autonomy of EU law'. ${ }^{163}$ Here, the CJEU acknowledged that the conclusion of 'an international agreement providing for the creation of a court responsible for the

155 Ibid at para. 163.

156 Ibid at para. 165.

157 Ibid at para. 166.

158 Ibid at para. 167.

159 Ibid at para. 169.

160 Ibid at para. 171 (referring to Case C-617/10, Åkerberg Fransson, ECLI:EU:C:2013:105).

${ }^{161}$ Ibid at para. 174 .

162 Ibid at para. 176.

163 Ibid at para. 179-200. 
interpretation of its provisions... is not, in principle, incompatible with EU law'. ${ }^{164}$ However, it identified three problems in the draft accession agreement. First, the CJEU emphasized how in Melloni it had interpreted Article 53 EU Charter 'as meaning that the application of national standards of protection of fundamental rights must not compromise the level of protection provided for by the Charter or the primacy, unity and effectiveness of EU law'. ${ }^{165}$ Yet, because Article 53 ECHR allows the contracting parties to go beyond the minimum protection guaranteed by the ECHR, the CJEU ruled that the accession agreement omitted to coordinate that clause "with Article 53 of the Charter, as interpreted by the [CJEU], so that the power granted to Member States by Article 53 of the ECHR is limited - with respect to the rights recognised by the Charter that correspond to those guaranteed by the ECHR - to that which is necessary to ensure that the level of protection provided for by the Charter and the primacy, unity and effectiveness of EU law are not compromised'. ${ }^{166}$

Secondly, the CJEU underlined 'the fundamental importance' of the principle of mutual trust between the Member States in EU law, ${ }^{167}$ and emphasized the risks that the accession agreement posed on it. Citing the N.S. case, the CJEU recalled that 'when implementing EU law, the Member States may, under EU law, be required to presume that fundamental rights have been observed by the other Member States'. ${ }^{168}$ Based on this, the CJEU affirmed the principle that 'by reason of their membership of the EU, accepted that relations between them as regards the matters covered by the transfer of powers from the Member States to the EU are governed by EU law to the exclusion, if EU law so requires, of any other law'. ${ }^{169}$ According to the CJEU, however, the draft accession agreement threatened to upset this situation:

In so far as the ECHR would, in requiring the EU and the Member States to be considered Contracting Parties not only in their relations with Contracting Parties which are not Member States of the EU but also in their relations with each other, including where such relations are governed by EU law, require a Member State to check that another Member State has observed fundamental rights, even though EU law imposes an obligation of mutual trust between those Member States, accession is liable to upset the underlying balance of the EU and undermine the autonomy of EU law. $^{170}$

Thirdly, the CJEU tackled another incompatibility between the accession agreement and EU law, that is, the possible circumvention of the preliminary ruling

164 Ibid at para. 182.

165 Ibid at para. 188 (referring to Case C-399/11, Melloni, ECLI:EU:C:2013:107).

166 Ibid at para. 189.

167 Ibid at para. 191 (referring to Joined Cases C-411/10 and C-493/10, N. S. and Others, ECLI:EU:C:2011:865).

168 Ibid at para. 192.

169 Ibid at para. 193.

170 Ibid at para. 194. 
procedure due to institutional innovations in the ECHR. As the CJEU pointed out, Protocol No 16 to the ECHR (which is currently subject to the process of national ratification) 'permits the highest courts and tribunals of the Member States to request the ECtHR to give advisory opinions on questions of principle relating to the interpretation or application of the rights and freedoms guaranteed by the ECHR'. ${ }^{171}$ However, the draft accession agreement did not take any measures to minimize the adverse effects of Protocol No 16 on Article 267 TFEU, with the consequence that it cannot be ruled out that a request for an advisory opinion made pursuant to Protocol No 16 by a court or tribunal of a Member State that has acceded to that protocol could... creat[e] a risk that the preliminary ruling procedure provided for in Article 267 TFEU might be circumvented'. ${ }^{172}$ In light of the three criticisms just described, the CJEU concluded that 'the accession of the EU to the ECHR as envisaged by the draft agreement is liable adversely to affect the specific characteristics of EU law and its autonomy'. ${ }^{173}$

After considering the compatibility of the draft accession agreement with the special characteristics of EU law, the CJEU engaged in a second, more specific, assessment, ${ }^{174}$ focusing on whether the draft accession agreement respected Article 344 TFEU, which prohibits Member States from submitting a dispute concerning the interpretation or the application of the Treaties to any method of settlement other than those provided therein. In this regard, the CJEU, after recalling its precedent in the Mox Plant dispute, ${ }^{175}$ affirmed that 'the obligation of Member States to have recourse to the procedures for settling disputes established by EU law - and, in particular, to respect the jurisdiction of the Court of Justice, which is a fundamental feature of the EU system-must be understood as a specific expression of Member States' more general duty of loyalty resulting from Article 4(3) TEU'. ${ }^{176}$ As the CJEU held, however, the draft accession agreement still allowed 'for the possibility that the EU or Member States might submit an application to the ECtHR, under Article 33 of the ECHR, concerning an alleged violation thereof by a Member State or the EU, respectively, in conjunction with EU law'. ${ }^{177}$ According to the CJEU, this state of affairs represented a violation of Article 344 TFEU, which vitiated the draft accession agreement. ${ }^{178}$

The CJEU subsequently examined the legal compatibility of the co-respondent mechanism, ${ }^{179}$ and of the prior involvement procedure ${ }^{180}$ — concluding that

${ }^{171}$ Ibid at para. 196.

172 Ibid at para. 198.

173 Ibid at para. 200.

${ }^{174}$ Ibid at para. $201-214$.

175 Ibid at para. 202 (referring to Case C-459/03, Mox Plant, ECLI:EU:C:2006:345).

176 Ibid at para. 202.

177 Ibid at para. 207.

178 Ibid at para. 213.

179 Ibid at para. 215-235.

180 Ibid at para. 236-248. 
neither of these devices envisaged in the accession agreement passed muster. On the one hand, as far as the co-respondent mechanism is concerned, the CJEU noted that the draft accession agreement, with a view to preventing gaps in the protection of human rights, foresaw that a contracting party to the ECHR 'is to become a co-respondent either by accepting an invitation from the ECtHR or by decision of the ECtHR upon the request of that Contracting Party'. ${ }^{181}$ As the CJEU argued, however, 'in carrying that review, the ECtHR would be required to assess the rules of EU law governing the division of powers between the EU and its Member States as well as the criteria for the attribution of their acts or omissions'. ${ }^{182}$ According to the CJEU this effectively allowed the ECtHR 'to interfere with the division of powers between the EU and its Member States'. ${ }^{183}$ Furthermore, this situation was aggravated by the possibility for the ECtHR deciding, in a case where both a state and the EU are corespondent, 'that only one of them is to be held responsible for th[e] violation'. ${ }^{184}$ Since this 'would be tantamount to allowing [the ECtHR] to take the place of the $[\mathrm{CJEU}]$ in order to settle a question that falls within the latter's exclusive jurisdiction', ${ }^{185}$ the ECJ ruled that the co-respondent mechanism ran afoul of EU treaty law.

On the other hand, the CJEU ruled that the prior involvement mechanism designed by the draft accession agreement was not sufficiently protective of its role. Even though the prior involvement mechanism had been largely required by the CJEU, as a way to satisfy 'the requirement that the competences of the EU and the powers of its institutions, notably the Court of Justice, be preserved', ${ }^{186}$ in the CJEU's view the draft accession agreement still left to the ECtHR the competence to determine 'whether the [CJEU] has already given a ruling on the same question of law as that at issue in the proceedings before the EctHR'. ${ }^{187}$ Moreover, in the CJEU's view, the draft accession agreement was framed in such language that the prior involvement mechanism could be activated only for the purpose of reviewing the validity of an EU act-and not also to empower the CJEU to rule on the interpretation of an EU act. ${ }^{188}$ Accordingly, the CJEU concluded that, by limiting the scope of the prior involvement procedure, in the case of secondary law, solely to questions of validity, the draft accession agreement 'adversely affect[ed] the competences of the EU and the powers of the [CJEU] in that it does not allow the Court to provide a definitive interpretation of secondary law in the light of the rights guaranteed by the ECHR'. ${ }^{189}$

\footnotetext{
${ }^{181}$ Ibid at para. 218.

182 Ibid at para. 224.

183 Ibid at para. 225.

${ }^{184}$ Ibid at para. 229.

185 Ibid at para. 234.

186 Ibid at para. 237.

187 Ibid at para. 238.

188 Ibid at para. 242.
} 
Lastly, the CJEU also assessed the draft accession agreement under a fifth aspect, concerning judicial review in the area of Common Foreign and Security Policy (CFSP). ${ }^{190}$ In this regard, the CJEU pointed out that its power of judicial review in CFSP matters is limited by the treaties, ${ }^{191}$ and that, 'as EU law now stands, certain acts adopted in the context of the CFSP fall outside the ambit of judicial review by the [CJEU]'. ${ }^{192}$ Yet, as the CJEU remarked, 'on the basis of accession as provided for by the agreement envisaged, the ECtHR would be empowered to rule on the compatibility with the ECHR of certain acts, actions or omissions performed in the context of the CFSP, and notably of those whose legality the Court of Justice cannot, for want of jurisdiction, review in the light of fundamental rights'. ${ }^{193}$ For the CJEU, therefore, the accession agreement would 'entrust the judicial review of those acts, actions or omissions on the part of the EU exclusively to a non-EU body' ${ }^{194}$ —and although this situation derived from the way 'in which the [CJEU]'s powers are structured at present, the fact remains that the agreement envisaged fails to have regard to the specific characteristics of EU law with regard to the judicial review of acts.' ${ }^{195}$

In light of all of the above, the CJEU concluded that the draft agreement on the accession of the EU to the ECHR was not compatible with the EU Treaties, because: (i) it is liable adversely to affect the specific characteristics and the autonomy of EU law in so far as it does not ensure coordination between Article 53 of the ECHR and Article 53 of the Charter, does not avert the risk that the principle of Member States' mutual trust under EU law may be undermined, and makes no provision in respect of the relationship between the mechanism established by Protocol No 16 and the preliminary ruling procedure provided for in Article 267 TFEU; (ii) it is liable to affect Article 344 TFEU in so far as it does not preclude the possibility of disputes between Member States or between Member States and the EU concerning the application of the ECHR within the scope ratione materiae of $\mathrm{EU}$ law being brought before the ECtHR; (iii) it does not lay down arrangements for the operation of the co-respondent mechanism and the procedure for the prior involvement of the CJEU that enable the specific characteristics of the EU and EU law to be preserved; and (iv) it fails to have regard to the specific characteristics of EU law with regard to the judicial review of acts, actions, or omissions on the part of the EU in CFSP matters in that it entrusts the judicial review of some of those acts, actions, or omissions exclusively to a non-EU body. ${ }^{196}$

189 Ibid at para. 247.

190 Ibid at para. 249-257.

191 Ibid at para. 249 (referring to Art 24(1) TEU).

192 Ibid at para. 252.

193 Ibid at para. 254.

194 Ibid at para. 255.

195 Ibid at para. 257.

196 Ibid at para. 258. 


\section{The possible future: towards a race to the top in human rights protection?}

Opinion 2/13 arguably crystallizes the current state of the relations between the CJEU and the ECtHR, and raises important questions about the future of the interaction between the two European supranational courts. Although some EU institutions, ${ }^{197}$ and several academics, ${ }^{198}$ have re-affirmed their commitment toward completing the accession process, perhaps through the drafting of a new accession agreement, it seems plausible to claim that the doors for EU accession to the ECHR are closed, at least for the foreseeable future. This leaves to the CJEU and the ECtHR once again the role, and the responsibility, to judicially shape the relation between the EU and ECHR legal orders. ${ }^{199}$ As Section II pointed out, for over 60 years the CJEU and the ECtHR had-with ups and downs - managed to co-exist in the European constitutional space, and there is the possibility that the relation between the CJEU and the ECtHR will continue in a 'business as usual' fashion. However, the ruling of the CJEU on the accession agreement may represent a turning point, and open a new confrontational phase. We believe this would not be a welcome development. Rather, we suggest that a virtuous competition between the CJEU and the ECtHR may carry added value for the protection of fundamental rights in Europe-even in the absence of formal accession. Each of these scenarios will be discussed in turn.

\section{A. Continuing comity}

While Opinion 2/13 has halted the process by which the EU would have become a contracting party to the ECHR—with the consequential subjection of EU institutions to the oversight of the ECtHR - the ruling of the CJEU has not altered the pre-existing context. As mentioned in Section II.C, the relation between the CJEU and the ECtHR in the first decade of the twenty-first century was shaped, on the one hand, by a significant expansion of human rights

197 See the Vice-President of the European Commission Frans Timmermans, Speech at the State of the Union Conference, European University Institute, 8 May 2015 (stating that even after Opinion $2 / 13$ the Commission is committed to accession).

198 See Christoph Krenn, 'Autonomy and Effectiveness as Common Concerns: A Path to ECHR Accession After Opinion 2/13’ (2015) 16 German Law Journal, 147 as well as Leonard Besselink, 'Acceding to the ECHR Notwithstanding the Court of Justice Opinion 2/13', available at <http:// www.verfassungsblog.de/en/acceding-echr-notwithstanding-court-justice-opinion-213/\#.Vk5NitrSRs $>$ (last accessed 18 February 2016).

199 See also Tobias Lock, 'The ECJ and the ECtHR: The Future Relationship Between the Two European Courts' (2009) 8 The Law and Practice of International Courts and Tribunals, 375 and Noreen O’Meara, “"A More Secure Europe of Rights?” The European Court of Human Rights, the Court of Justice of the European Union, and EU Accession to the ECHR' (2011) 12 German Law Journal, 1813. 
protection in the EU legal order, ${ }^{200}$ and, on the other, by a presumption that the human rights standards of the EU go beyond the floor of protection of the ECHR. ${ }^{201}$ Ceteris paribus, a possible scenario for the future is that the ECtHR may therefore continue to apply its deferential Bosphorus doctrine, refusing to review state actions which implement EU law, unless the system of human rights protection existing in the EU legal order becomes deficient. In fact, the potential of a continuing relation of comity between the CJEU and the ECtHR might be substantiated by further recent developments in the case law of the CJEU, which have increasingly pushed the CJEU to play the role of a human rights court on the basis of the EU Charter of Fundamental Rights. ${ }^{202}$

This development is visible in particular in the field of privacy and data protection. Through a series of milestone judgments, during the last few years the CJEU has taken the lead in the protection of human rights in the digital world. ${ }^{203}$ Among others, the CJEU held that individuals have a fundamental right to be protected against systematic retention of personal data for law enforcement purposes, thus striking down the EU Data Retention Directive. ${ }^{204}$ It ruled that data subjects have a right to request removal of data about them from online search engines, recognizing a right to be forgotten. ${ }^{205}$ And it required that transfer of data to third countries be subject to the same level of protection that apply domestically, invalidating the safe harbour agreement allowing companies to exchange data between the EU and the USA. ${ }^{206}$ Compared to the vanguard case law of the CJEU, in the field of privacy the ECtHR has embraced a more prudent approach, notably when data protection principles conflicted with national security concerns. ${ }^{207}$ Given this state of affairs, it might be that the ECtHR will—albeit grudgingly—reaffirm its Bosphorus presumption, and maintain a committal approach toward the CJEU, and the EU legal order.

However, we are aware that this development may not be the most likely one. As multiple observers have pointed out, the wording of Opinion 2/13 revealed a potentially dismissive approach by the CJEU vis-à-vis the ECtHR, and the unwillingness of the former to subject itself to external review by the latter. ${ }^{208}$

200 See Sybe de Vries, Ulf Bernitz and Stephen Weatherill (eds), The EU Charter of Fundamental Rights as a Binding Instrument (Oxford: Hart Publishing, 2015).

${ }_{201}$ See Bosphorus (n 81).

202 Gráinne De Búrca, 'After the EU Charter of Fundamental Rights: The Court of Justice as a Human Rights Adjudicator?' (2013) 20 Maastricht Journal of European and Comparative Law, 168.

203 See Federico Fabbrini, 'The EU Charter of Fundamental Rights and the Right to Data Privacy: the ECJ as a Human Rights Court' in de Vries, Bernitz and Weatherill (n 200) 261.

${ }^{204}$ Joined Cases C-293/12 and C-594/12, Digital Rights Ireland, ECLI:EU:C:2014:238.

205 Case C-131/12, Google Spain, ECLI:EU:C:2014:317.

206 Case C-362/14, Schrems, ECLI:EU:C:2015:650.

207 See also Federico Fabbrini, 'Human Rights in the Digital Age' (2015) 28 Harvard Human Rights Journal, 65.

208 See Louise Storgaard, 'EU Law Autonomy versus European Fundamental Rights ProtectionOn Opinion 2/13 on the EU Accession to the ECHR' (2015) 15 Human Rights Law Review, 485; and Piet Eeckout, 'Opinion 2/13 on EU Accession to the ECHR and Judicial Dialogue: Autonomy or Autarky?' (2015) 38 Fordham International Law Journal, 955. 
In turn, this may produce a negative reaction in the ECtHR, prompting it to set aside its committal approach and find ways to respond to the CJEU, and to reaffirm its status. In fact, the displeasure with which the ECtHR has taken notice of the opinion of the CJEU was visibly on display in Strasbourg in March 2015 at the delivery of the report about the court's judicial activities during the previous year, where the President of the ECtHR openly described the CJEU's 'unfavorable opinion [a]s a great disappointment'. ${ }^{209}$ Given the experience described in Section II.B., therefore, it cannot be excluded that rather than continuing comity, the relationship between the CJEU and the ECtHR may turn into one of confrontation.

\section{B. New confrontation}

Since the EU is not a contracting party to the ECHR, the ECtHR could not subject action by the EU institutions - including judgments by the CJEU - to its review. However, if the interaction between the CJEU and the ECtHR is going to become more acrimonious, there are multiple ways in which the latter could act against the former. On the one hand, the ECtHR has never set aside the Matthews doctrine, and it could explore further areas where the CJEU has no full jurisdiction, with the effect of expanding its oversight on EU action (or more precisely, action by the EU Member States qua organs of the EU). On the other hand, the ECtHR could reconsider its Bosphorus doctrine, rebutting the presumption that EU Member States' action in compliance with an EU mandate respects the ECHR, thus also extending its review to the multiple fields where the States simply execute EU laws. Given the breath of EU competences, if the ECtHR were to reconsider the Bosphorus presumption, this would effectively open the backdoor to an ECHR review of EU acts, creating a potentially explosive situation where EU Member States would be liable for faults of the EU (exactly the situation that the draft accession agreement was set to avoid, through the idea of the co-respondent mechanism).

In fact, a glimpse of the difficulties which would arise under this scenario was offered by the recent litigation concerning the right of asylum seekers under the framework of the Dublin Regulation. ${ }^{210}$ As is well known, the Dublin Regulation required asylum applications by third country nationals to be processed by the first EU Member State of entry, but the ECtHR ruled that States were prohibited from transferring asylum seekers back to the State of entry when this failed to ensure adequate human rights standards. ${ }^{211}$ While the CJEU, ${ }^{212}$

\footnotetext{
209 European Court of Human Rights, Annual Report 2014, Strasbourg 2015, 6.

210 Regulation (EU) 604/2013 of the European Parliament and of the Council of 26 June 2013 establishing the criteria and mechanisms for determining the Member State responsible for examining an application for international protection lodged in one of the Member States by a third-country national or a stateless person [2013] OJ L 180/31.

${ }^{211}$ Application no 30696/09, M.S.S. v Belgium and Greece, ECLI:CE:ECHR:2011:0121JUD003 069609 .

212 See N. S. (n 167).
} 
and the EU legislator, ${ }^{213}$ eventually embraced the ECtHR approach, introducing an exception to the country of first entry rule in EU law, the judgment of the ECtHR effectively impacted on a measure of EU law, exposing the weak point of the trust between Member States which was at the basis of the EU regulation. In the end, events, more than judicial opinions, toppled the Dublin Regulation - which had in any case been unfair and immoral since its entry into force. ${ }^{214}$ Yet, this example also reveals how, if the ECtHR wanted to embrace a confrontational approach vis-à-vis the CJEU, it could deeply affect the functioning of the EU legal order.

However, we are of the view that a new phase of trans-European judicial clash would not be welcome-let alone in the interest of the ECtHR. While the CJEU did not make many friends in Brussels or Strasbourg with Opinion 2/13, the ECtHR does not have many friends in Member States capitals either. As has been recently pointed out, the ECtHR faces a crisis of legitimacy ${ }^{215}$ —especially because of the staunch opposition which has emerged in a number of EU Member States, prominently the United Kingdom, against its decisions. ${ }^{216}$ While opposition to the ECtHR is largely ideological, and does not do justice to the crucial role that the ECtHR has played in promoting a human rights culture throughout Europe, ${ }^{217}$ this is a factor that the ECtHR cannot fail to take into account. In this situation, it would not be ideal for the ECtHR to be seen as haranguing the CJEU, and even more so EU Member States implementing EU law. Rather than opening a new front-line against the EU, it would therefore seem prudent for the ECtHR instead to engage in a more creative, and yet potentially more fruitful, competition with the CJEU to raise the standards of human rights protection in Europe.

\section{Virtuous competition?}

The existence of two supranational courts dealing with the protection of fundamental rights in Europe has been criticized as as being over-complex on more

213 See Art. 33 Regulation (EU) 604/2013.

214 See German Chancellor Angela Merkel, Speech, 25 August 2015 (declaring suspension of Dublin Regulation and willingness to process asylum applications of Syrian refugees in Germany, even though they had first entered other EU Member States).

215 See Jonas Christoffersen and Mikael Madsen (eds), The European Court of Human Rights between Law and Politics (Cambridge: Cambridge University Press, 2011) and Spyron Flogaitis, Tom Zwart and Julie Fraser (eds), The European Court of Human Rights and its Discontents (Cheltenham: Elgar, 2013).

216 See especially the British responses to Application no 74025/01, Hirst $v$ UK, ECLI:CE:ECHR:2005:1006JUD007402501 (ECtHR ruling the UK to be in violation of Article 3 of the 1st additional Protocol to the ECHR for depriving felons of voting rights): House of Commons 10 February 2011: Column 493 (Mr Davis MP asking: 'is the requirement to give prisoners the vote sensible, just, right and proper? Secondly, who should decide? Should it be the [ECtHR], or this House on behalf of the British people?').

217 See Vladimiro Zagrebelsky, 'Note sulle conclusion della Conferenza di Brighton "Per assicurare il futuro della Corte europea dei diritti dell'Uomo"' (2014) 4 Rivista Associazione Italiana dei Costituzionalisti, 1. 
than one occasion. For legal minds framed in the unitary legal architecture of the state, the pluralism of supranational jurisdictions, and courts, can only be the object of confusion. And yet, as much as in the market the existence of multiple producers and products is a pre-condition to improving quality, in the field of fundamental rights in Europe, the competition between supranational courts can also be seen as playing an important role in the promotion and protection of human rights. While the market metaphor may be inappropriate in the human rights context, what we want to suggest is that the interaction between the CJEU and the ECtHR may actually exert a positive effect on the protection of fundamental rights, creating a virtuous race to the top in the protection of fundamental rights - a development which is certainly in the interest of human rights. In other words, we think that even in the aftermath of Opinion 2/13 there is space for the CJEU and the ECtHR to coexist without clashing, and instead to raise and push forward the protection of fundamental rights in Europe.

An emblematic example of this is offered by the case of judicial review of targeted UN sanctions. As we explained in depth elsewhere, ${ }^{218}$ the CJEU and the ECtHR were both asked to rule on the legality of counter-terrorism measures against individuals adopted by the UN Security Council, which compelled Member States, or EU institutions, to freeze the funds, or restrict the freedom of movement, of individuals suspected of being involved in financing terrorism. Through a subsequent series of judgments, both the CJEU and the ECtHR intensified their review of the UN counter-terrorism regime, introducing core due process and fair trial guarantees into the system. Crucially, in doing so, the CJEU and the ECtHR drew from each other's example, and simultaneously pushed each other to adopt even more expansive human rights approaches. In fact, it is precisely the competition between the CJEU and the ECtHR, and their desire to operate as the leading human rights court in Europe, that has allowed them to exercise judicial review of UN sanctions, and to entrench the protection of fundamental rights of terrorist suspects even against continuing pressures to sacrifice civil liberties to national security imperatives. ${ }^{219}$

The Kadi and Nada stories are well known, ${ }^{220}$ but it is worth briefly recounting the interactions between the CJEU and the ECtHR to emphasize the point we want to make here: that a sound competition between the two European supranational courts can have virtuous effects on the protection of human rights in Europe. After the EU Court of First Instance (now called the

${ }^{218}$ Federico Fabbrini and Joris Larik, 'Global Counter-Terrorism Sanctions and European Due Process Rules: The Dialogue Between the CJEU and the ECtHR', in Matej Avbelj, Filippo Fontanelli, and Giuseppe Martinico (eds), Kadi on Trial: A Multifaceted Analysis of the Kadi Judgment (Abingdon: Routledge, 2014) 135.

219 See Deirdre Curtin and Christina Eckes, 'The Kadi Case: Mapping the Boundaries Between the Executive and the Judiciary in Europe' (2009) 5 International Organization Law Review, 365.

${ }^{220}$ Erika de Wet, 'From Kadi to Nada: Judicial Techniques Favouring Human Rights over United Nations Security Council Sanctions' (2013) 12 Chinese Journal of International Law, 787. 
General Court) ruled in 2005 that it could only review the black-listing of $\mathrm{Mr}$ Kadi for compliance with jus cogens ${ }^{221}$-a position followed pari passu by the Swiss Federal Supreme Court in its 2007 ruling on $\mathrm{Mr} \mathrm{Nada}^{222}$ - the CJEU famously ruled in 2008 that it had the power to ensure the full review of restrictive measures adopted against individuals suspected of being involved in terrorism, regardless of the fact that these were required by virtue of UN Security Council resolutions. ${ }^{223}$ While the CJEU judgment was followed in 2010 by the EU General Court in Kadi $I I,{ }^{224}$ the ECtHR clearly draw on it as well. In its 2012 Nada ruling (on appeal from the Swiss Federal Supreme Court), the Grand Chamber of the ECtHR found that Switzerland had violated the ECHR in the implementation of UN sanctions, and citing the CJEU in Kadi, signalled its view that UN action could not cavalier ECHR guarantees. ${ }^{225}$ In 2013, on the contrary, the CJEU in Kadi II took notice of the ECtHR ruling in Nada, and-rejecting the advice of the Advocate General to tone down its human rights stance 226 - affirmed instead the rule that EU fundamental rights required EU institutions (and arguably UN authorities) to delist individuals unless they are willing or able to fully disclose the evidence against them. ${ }^{227}$

As has been pointed out, the competition between the CJEU and the ECtHR in the context of judicial review of UN sanctions has been crucial in strengthening the protection of fundamental rights, and to resist the security pressures coming from the political branches of government at national, supranational, and international level. ${ }^{228}$ While in Nada the ECtHR followed the judicial path offered by the CJEU, finding in Kadi I a powerful argument to exercise judicial review of UN Security Council resolutions, it also sought to go beyond the CJEU, holding that UN states have an array of positive obligations to seek in UN fora the delisting of persons who have been cleared in terrorism-related domestic investigations and to help them make full use of exceptions provided in the regime (eg for medical or family reasons). At the same time, while in Kadi II the CJEU found in Nada support to stand its ground against voices

221 Case T-315/01, Kadi v Council and Commission, ECLI:EU:T:2005:332.

222 Youssef Nada $v$ State Secretariat for Economic Affairs and Federal Department of Economic Affairs, Administrative appeal judgment, Case No 1A 45/2007, ILDC 461 (CH 2007), BGE 133 II 450.

223 Joined Cases C-402/05 P and C-415/05 P, Kadi and Al Barakaat, ECLI:EU:C:2008:461.

224 Case T-85/09, Kadi v Commission, ECLI:EU:T:2010:418.

225 Application no 10593/08, Nada v Switzerland, ECLI:CE:ECHR:2012:0912JUD001059308 (referring to Kadi and Al Barakaat (n 223) at para. 83-87, 176, and 212).

226 Joined Cases C-584/10 P, C-593/10 P and C-595/10 P, Kadi II, Opinion of Advocate General Bot, ECLI:EU:C:2013:176.

227 Joined Cases C-584/10 P, C-593/10 P and C-595/10 P, Kadi II, ECLI:EU:C:2013:518 (referring to Nada $v$ Switzerland (n 225) at para. 133).

228 See also Erika de Wet, 'Implicit Judicial Favouring of Human Rights over United Nations Security Council Sanctions: A Manifestation of International Constitutionalism?' in Federico Fabbrini and Vicki Jackson (eds), Constitutionalism Across Borders in the Struggle Against Terrorism (Cheltenham: Edward Elgar, 2016) 35. 
demanding it to lower its human rights standard, it pushed its argument one step further, too, introducing a clear 'disclose or delist' rule. The combined effect of Kadi and Nada has therefore been to uphold human rights guarantees in Europe, and encourage the introduction of a more human rights friendly approach in the anti-terrorism regime set up at the global level, overcoming what international lawyers had identified as its original $\sin .229$

The example of Kadi and Nada shows the path of a possible way forward for the CJEU and the ECtHR, in which the two courts compete to play a leading role in human rights protection, with virtuous effects for fundamental rights in Europe. As we claimed, 'a rivalling, yet constructive, relationship between the two courts worked in a beneficial manner for fundamental rights'.230 Admittedly, this statement predated Opinion 2/13. Arguably, however, the competition between the CJEU and the ECtHR can still continue to ensure an incremental improvement of human rights protection in Europe, even in the aftermath of Opinion 2/13. Although we are aware that the case of judicial review of UN sanctions is just one example, we want to suggest that the existence of two separate jurisdictions involved in human rights protection in Europe may be beneficial for fundamental rights, generally. For this to take place, the CJEU, on the one hand, would have to keep an open eye and mind towards the ECtHR case law; ${ }^{231}$ and the ECtHR, on the other hand, would need to step up its human rights approach-likely overcoming the haphazard use of the margin of appreciation it has made in recent times. ${ }^{232}$ Even though the ECtHR will not have jurisdiction on the $\mathrm{EU}$ in the foreseeable future, it still has competence to review human rights compliance by 47 Member States_including 19 countries which are not members of the EU (and where violations of human rights are often blatant). ${ }^{233}$ If the ECtHR will take seriously its task to promote and protect fundamental rights within its jurisdiction, it could continue to offer a stimulus also on the CJEU to raising and expanding the protection of human rights in the EU.

\footnotetext{
229 See also Martin Scheinin, 'United Nations Law: Substantive Constitutionalism through Human Rights vs Formal Hierarchy through Article 103', in Fabbrini and Jackson (n 228) 15.

230 Fabbrini and Larik (n 218) 155.

231 See also Art. 52(3) EU Charter (saying that provisions of the Charter that track the ECHR should be interpreted in conformity with the ECHR) as well as Juliane Kokott and Christoph Sobotta, 'Protection of Fundamental Rights in the European Union' (2015) 34 Yearbook of European Law, 60.

232 See Application no 25579/05, A B and C v Ireland, ECLI:CE:ECHR:2010:1216JUD002 557905 (holding that restrictions of abortion in Ireland fall within the state's margin of appreciation notwithstanding the existence of a wide consensus in Europe in favour of abortion rights) and Application no 30814/06, Lautsi v Italy, ECLI:CE:ECHR:2011:0318JUD003081406 (recognizing that Italy enjoyed a margin of appreciation in displaying the crucifix for cultural reasons), on which see critically Susanna Mancini, 'The Crucifix Rage: Supranational Constitutionalism Bumps against the Counter-Majoritarian Difficulty' (2010) 6 European Constitution Law Review, 6.

233 See United States Department of State, Human Rights Report (2014), <http://www.state.gov/j/ $\mathrm{drl} / \mathrm{rl} / \mathrm{h} / \mathrm{hrpt} /$ humanrightsreport/index.htm\#wrapper $>$ (discussing human rights shortcomings) (last accessed 18 February 2016).
} 
We are aware of important caveats, which should be made as qualifications to the argument we are advancing here. First, as we mentioned, the ECtHR is currently facing a crisis of legitimacy, and it may not be really feasible for it to take forward the torch of human rights, inaugurating a new progressive approach, for instance on issues such as gay marriage. ${ }^{234}$ Secondly, the fact that the ECtHR is often not leading in areas of human rights protection is just the result of the application of the margin of appreciation, which allows States to adopt different standards of protection when there is no European consensus. ${ }^{235}$ Thirdly, pushing forward the protection of fundamental rights is not an exercise without costs: in fact, rights are always in a balance, and protecting more and more one given right may simultaneously imply restricting other rights, or public interests - which may be of equal or greater importance. ${ }^{236}$ Yet, if the $\mathrm{CJEU}$ and the ECtHR co-exist in the European constitutional space, the most virtuous way for them to do so is by taking seriously together the task of which they are mandated by the ECHR and now the EU treaties: securing and protecting fundamental rights in Europe, ${ }^{237}$ particularly in areas where the political process is unable to internalize the interests of insulated minorities, or disfavoured groups.

\section{Conclusion}

In Opinion 2/13 delivered in December 2014, the CJEU declared the draft agreement on the EU accession to the ECHR as incompatible with the EU treaties, thereby halting the process aimed at officially linking the $\mathrm{EU}$ and the ECHR human rights systems. The ruling of the CJEU has triggered multiple criticisms, but the purpose of this article has not been to debate Opinion 2/13. Rather, taking a long-term perspective, this article has sought to recall and contextualize the long background of past relations between the CJEU and the ECtHR, and to consider how this may evolve in the future. For more than 60 years, the CJEU and the ECtHR have engaged in a judicial exchange,

\footnotetext{
${ }^{234}$ See Applications nos 18766/11 and 36030/11, Oliari and others, ECLI:CE:ECHR:2015:0721JUD001876611.

235 See Marta Cartabia, 'Editorial: When Rights are Controversial, are Dialogues between Courts still Enough?' (2010) 1 Italian Journal of Public Law, 1.

236 See Joseph Weiler, 'Editorial: Individual and Rights-The Sour Grapes' (2010) 21 European Journal of International Law, 2.

237 Compare David Thor Björgvinsson, The Role of Judges of the ECtHR as Guardians of Fundamental Rights of the Individual, iCourts Working Paper No. 23/2015 (emphasizing importance of protecting human rights by the ECtHR) with Allan Rosas, 'Five Years of Charter Case Law: Some Observations' in de Vries, Bernitz and Weatherill (n 200) 14 (emphasizing importance of protecting human rights by the CJEU).
} 
which has gone through multiple phases: from separation, to conflict, to comity. Opinion 2/13 puts a spanner in the process of formalizing the relation between the two courts and their legal orders. However, it does not, and cannot, end their interaction in the shared European constitutional space. In the absence of $\mathrm{EU}$ accession to the ECHR, at least for the foreseeable future, informal dialogue will continue to be the defining feature of the relation between the CJEU and the ECtHR. Yet, as this article has discussed, while continuing comity by the ECtHR vis-à-vis the CJEU may be unlikely given Opinion 2/13, a new conflict between the two European supranational courts would be unwelcome and ultimately detrimental to both courts. As an alternative, the article pointed to another possible path, claiming that virtuous competition between the CJEU and the ECtHR may produce beneficial effects for the protection of fundamental rights in Europe. By analysing the case of judicial review of UN counterterrorism sanctions, the article underlined how the existence of two transnational courts involved in human rights protection produced a race to the top, strengthening liberties despite national security concerns. At a time when much frustration and preoccupation exist on the future of the relation between the CJEU and the ECtHR, therefore, the article sought to strike a note of optimism, suggesting that the two European supranational courts can jointly play a valuable role in promoting the growth and development of fundamental rights in Europe. 